\title{
Reactive Oxygen Species Generation in Human Cells by a Novel Magnetic Resonance Imaging Contrast Agent
}

\author{
Li Wang, ${ }^{1}$ Eric Lin, ${ }^{1}$ Mary J. Johansen, ${ }^{2}$ Timothy Madden, ${ }^{3}$ Edward Felix, ${ }^{4}$ \\ Karen S. Martirosyan, ${ }^{5}$ and Steven J. Frank $\mathbb{1}^{6}$ \\ ${ }^{1}$ Department of Experimental Radiation Oncology, The University of Texas MD Anderson Cancer Center, Houston, TX, USA \\ ${ }^{2}$ Strategia Therapeutics, Inc., Boston, MA, USA \\ ${ }^{3}$ InPharma LLC, The Woodlands, TX, USA \\ ${ }^{4}$ Department of Experimental Therapeutics, The University of Texas MD Anderson Cancer Center, Houston, TX, USA \\ ${ }^{5}$ Department of Physics, University of Texas Rio Grande Valley, Rio Grande Valley, TX, USA \\ ${ }^{6}$ Department of Radiation Oncology, The University of Texas MD Anderson Cancer Center, Houston, TX, USA
}

Correspondence should be addressed to Steven J. Frank; sjfrank@mdanderson.org

Received 12 October 2017; Accepted 19 February 2018; Published 26 March 2018

Academic Editor: Robert Tanguay

Copyright (C) $2018 \mathrm{Li}$ Wang et al. This is an open access article distributed under the Creative Commons Attribution License, which permits unrestricted use, distribution, and reproduction in any medium, provided the original work is properly cited.

The novel positive-contrast magnetic resonance imaging (MRI) marker C4 consists of an aqueous solution of cobalt chloride $\left(\mathrm{CoCl}_{2}\right)$ complexed with the chelator $\mathrm{N}$-acetylcysteine (NAC). We evaluated whether the presence of $\mathrm{C} 4$ or its components would produce reactive oxygen species (ROS, including hydroxyl, peroxyl, or other reactive oxygen species) in cultured cells. Human cancer or normal cells were incubated with $1 \%(\mathrm{w} / \mathrm{v}) \mathrm{CoCl}_{2} \cdot 6 \mathrm{H}_{2} \mathrm{O}$ or $2 \%$ NAC or a combination of both $\left(1 \% \mathrm{CoCl}_{2} \cdot 6 \mathrm{H}_{2} \mathrm{O}: 2 \%\right.$ $\mathrm{NAC}$ in an aqueous solution, abbreviated as $\mathrm{Co}$ : NAC) in the presence or absence of $\mathrm{H}_{2} \mathrm{O}_{2}$. Intracellular ROS levels were measured and quantified by change in relative fluorescence units. Student's $t$-tests were used. In all cell lines exposed to $1000 \mu \mathrm{M} \mathrm{H}_{2} \mathrm{O}_{2}$, the Co : NAC led to $\geq 94.7 \%$ suppression of ROS at 5 minutes and completely suppressed ROS at 60 and 90 minutes; NAC suppressed ROS by $\geq 76.6 \%$ at 5 minutes and by $\geq 94.5 \%$ at 90 minutes; and $\mathrm{CoCl}_{2} \cdot 6 \mathrm{H}_{2} \mathrm{O}$ suppressed $\mathrm{ROS}$ by $\geq 37.2 \%$ at 30 minutes and by $\geq 48.6 \%$ at 90 minutes. These results demonstrate that neither Co : NAC nor its components generated ROS; rather, they suppressed ROS production in cultured cells, suggesting that C4 would not enhance ROS production in clinical use.

\section{Introduction}

Prostate cancer is the most common type of cancer among men in the United States [1]. Low-dose-rate brachytherapy is a treatment option for men with low-risk or favorable intermediate-risk prostate cancer, providing cure rates similar to those of intensity-modulated radiation therapy [2, 3] more cost-effectively and with less severe declines in bowel health-related quality of life [4]. Oncologic outcomes and treatment-related toxicity after low-dose-rate brachytherapy depend greatly on the quality of the implant, which in turn depends on accurate placement and dose distribution of the radioactive seeds. Quality assurance efforts traditionally rely on computed tomography, which visualizes radioactive titanium seeds well but is not optimal for visualizing soft tissues such as the prostate and surrounding tissues. Magnetic resonance imaging (MRI) visualizes soft tissues well $[5,6]$ but requires a positive-contrast marker to precisely identify radioactive seeds [7].

Cobalt in its ionized form $\left(\mathrm{Co}^{2+}\right.$ or $\left.\mathrm{Co}(\mathrm{II})\right)$ has paramagnetic properties that generate positive-contrast signals on T1-weighted MRI. We developed an MRI marker in which cobalt chloride $\left(\mathrm{CoCl}_{2}\right)$ is complexed with 6 water molecules $\left(\mathrm{H}_{2} \mathrm{O}\right)$ and the chelating antioxidant $\mathrm{N}$-acetylcysteine (NAC). The resulting "cobalt complex contrast aqua solution," or "C4," is being tested for use in MRI-guided seed implantation in men undergoing brachytherapy for prostate cancer [7]. We have verified that the C4 MRI marker can improve visualization and localization of implanted radioactive seeds during and after implantation, and we are exploring its use to 
improve quality assurance and assessment of effectiveness in brachytherapy [8].

Cobalt is a naturally occurring element. In humans, a single cobalt atom is the central metal component of vitamin $\mathrm{B}_{12}$, a cofactor and activator of several essential enzymes that is present in most tissues, chiefly in the liver [9]. Although vitamin $B_{12}$ is essential for erythrocyte formation, protein metabolism, and central nervous system function, cobalt and its related compounds can induce oxidative stress [10-12]. Cobalt ions have been observed to generate reactive oxygen species (ROS) in vivo and in vitro, and $\mathrm{CoCl}_{2}$ has been shown to induce the formation of hydroxyl radicals $\left({ }^{\circ} \mathrm{OH}\right)$ from hydrogen peroxide $\left(\mathrm{H}_{2} \mathrm{O}_{2}\right)$ [13]. Thus, the US Department of Health and Human Services established a minimal risk level for cobalt $(0.01 \mathrm{mg} / \mathrm{kg} /$ day $)$ [9].

The potential toxicity caused by the inadvertent release of cobalt in C4 from temporarily or permanently implanted medical devices is unknown. To reduce the potential body burden of C4 cobalt, we chelated cobalt with NAC, which is known to increase both urinary and fecal excretion of cobalt and decrease cobalt levels in the liver and spleen [14]. The purpose of the current study was to test whether the components of $\mathrm{C} 4$, individually or in combination, would produce reactive oxygen species including hydroxyl and peroxyl in cultured cells.

\section{Materials and Methods}

2.1. Cell Cultures. The human prostate cancer cell line PC3 and the human normal tongue cell line Hs-680Tg were obtained from the American Type Culture Collection (Manassas, VA, USA). The human head and neck cancer cell line HN5 was supplied by Dr. Jeffrey Myers (University of Texas MD Anderson Cancer Center, Houston, TX, USA). HN5 and Hs-680Tg cells were maintained in DMEM/F-12 medium (Corning Cellgro, Mediatech, Inc., Manassas, VA, USA). PC3 cells were maintained in RPMI-1640 medium (Sigma-Aldrich, St. Louis, MO, USA). All culture media were supplemented with $10 \%$ fetal bovine serum (FBS, SigmaAldrich), $100 \mathrm{U} / \mathrm{mL}$ penicillin, and $100 \mu \mathrm{g} / \mathrm{mL}$ streptomycin (Gibco, Thermo Fisher, Grand Island, NY, USA). Cells were grown as monolayers in $75 \mathrm{~cm}^{2}$ flasks and maintained in a humidified $5 \% \mathrm{CO}_{2} / 95 \%$ air atmosphere at $37^{\circ} \mathrm{C}$. The identities of all cell lines were confirmed by genotyping (STR profiling) at MD Anderson's Characterized Cell Line Core Facility (NCI Core Grant CA016672).

2.2. Intracellular ROS Assay. Intracellular ROS levels were measured by using OxiSelect Intracellular ROS Assay Kits (Cell Biolabs, San Diego, CA, USA), which can be used to measure the activity of ROS (hydroxyl, peroxyl, and other reactive oxygen species) within a cell, according to the manufacturer's instructions. The assay uses the cell-permeable fluorogenic probe $2^{\prime}, 7^{\prime}$-dichlorodihydrofluorescein diacetate (DCFHDA), which upon diffusion into cells is deacetylated by cellular esterases to form a nonfluorescent compound that is then rapidly oxidized by ROS to create highly fluorescent $2^{\prime}, 7^{\prime}$-dichlorodihydrofluorescein (DCF). The green fluorescence intensity is proportional to the ROS levels within the cytosol [15]. The effects of antioxidants or free radical compounds on DCFHDA can be measured in terms of relative fluorescence units (RFUs). Fluorescence was measured with a VICTOR X3 multilabel plate reader (PerkinElmer, Inc., Wentzville, MO, USA) at excitation and emission wavelengths of $485 \mathrm{~nm}$ and $535 \mathrm{~nm}$, and RFUs were quantified with PerkinElmer 2030 software.

2.3. Preparation of Reagents and Test Solutions. Opti-MEM (Phenol Red-negative) medium (Gibco) without FBS was used to prepare the working solution of $1000 \mu \mathrm{M} \mathrm{H}_{2} \mathrm{O}_{2}$ (diluted from an $882 \mathrm{mM} \mathrm{H}_{2} \mathrm{O}_{2}$ stock [Thermo Fisher Scientific, Waltham, MA, USA]), the serial dilution of DCF to generate standard curves, and the $1 \mathrm{x}$ working solution of DCFHDA (diluted from a 20x stock supplied in the ROS Assay Kit). All the above solutions were protected from light and used immediately upon dilution. Test materials included cobalt chloride hexahydrate $\left(\mathrm{CoCl}_{2}-6 \mathrm{H}_{2} \mathrm{O}\right.$, Fluka SigmaAldrich 60820, Lot 1313139) and N-acetylcysteine (NAC, Sigma-Aldrich 47250-1006, Lot 051M1820V). The ingredients were dissolved in distilled water to create weight by volume percentage $(\mathrm{w} / \mathrm{v} \%$, where $1 \%=1 \mathrm{~g} / 100 \mathrm{~mL})$ concentrations for use. Stock solutions of $10 \% \mathrm{CoCl}_{2} 6 \mathrm{H}_{2} \mathrm{O}, 20 \% \mathrm{NAC}$, and $10 \% \mathrm{CoCl}_{2} \cdot 6 \mathrm{H}_{2} \mathrm{O}: 20 \%$ NAC (Co: NAC [10\%:20\%]) were prepared. Final concentrations of $1 \% \mathrm{CoCl}_{2} \cdot 6 \mathrm{H}_{2} \mathrm{O}, 2 \% \mathrm{NAC}$, and $\mathrm{Co}: \mathrm{NAC}(1 \%: 2 \%$, i.e., C4) were used to treat cells in FBS-free Opti-MEM (Phenol Red-negative) medium.

2.4. ROS Staining and Quantification. Each cell sample was assayed in triplicate. Cells were counted with a TC 20 Automated Cell Counter (Bio-Rad Laboratories, Inc., Hercules, CA, USA). A specific number of cells (for HN5, $5 \times 10^{3}$ cells/well; for Hs-680Tg, $8 \times 10^{3}$ cells/well; and for PC3, $1 \times$ $10^{4}$ cells/well, all cells in $100 \mu \mathrm{L}$ culture medium) were plated in clear-bottom black 96-well cell-culture plates and cultured for 24 hours. Cells were then washed with phosphate-buffered saline (PBS, Corning Cellgro) 3 times before $100 \mu \mathrm{L}$ of the 1x (for HN5 and Hs-680Tg cells) or $0.5 \mathrm{x}$ (for PC3 cells) DCFHDA/FBS-free Opti-MEM medium solution was added to each well. Plates were then incubated at $37^{\circ} \mathrm{C}$ for 30 minutes. The 1x DCFHDA/FBS-free Opti-MEM medium solution was then removed and the cells were washed 4 times with PBS. After the final wash, $90 \mu \mathrm{L}$ of FBS-free OptiMEM medium, or $90 \mu \mathrm{L}$ of $1000 \mu \mathrm{M} \mathrm{H}_{2} \mathrm{O}_{2}$ FBS-free OptiMEM medium solution, was added to each well. Immediately thereafter, $10 \mu \mathrm{L}$ of the $10 \% \mathrm{CoCl}_{2} \cdot 6 \mathrm{H}_{2} \mathrm{O}$, or the $20 \% \mathrm{NAC}$, or the Co : NAC ( $10 \%: 20 \%)$ was added to each well according to the different treatment conditions, and cells were incubated at $37^{\circ} \mathrm{C}$. The plates were read and fluorescence was quantified before and at different times (5, 30, 60, and 90 minutes) after treatment. ROS content was reported as RFUs.

2.5. Cell Morphology Analysis. Each cell sample was assayed in triplicate. Cells were counted with a TC 20 Automated Cell Counter (Bio-Rad Laboratories, Inc., Hercules, CA, USA). A specific number of cells (for $\mathrm{HN} 5,5 \times 10^{3}$ cells/well; for Hs-680Tg, $8 \times 10^{3}$ cells/well; and for PC3, $1 \times 10^{4}$ cells/well, all cells in $100 \mu \mathrm{L}$ culture medium) were plated 
in clear 96-well cell-culture plates overnight and then cells were treated with the greatest clinical exposure concentration (i.e., if 120 markers [the maximum number likely to be used in one patient with a prostate volume of $60 \mathrm{cc}$ ] were to leak simultaneously into the human periprostatic area after implantation) of $\mathrm{C} 4$ or its components $\left(1 \% \mathrm{CoCl}_{2} \cdot 6 \mathrm{H}_{2} \mathrm{O}\right.$, or the $2 \%$ NAC, or the Co:NAC [1\%:2\%]), and cells were incubated at $37^{\circ} \mathrm{C}$. At 90 minutes after treatment, pictures of cells were taken with a bright field Evos XL core microscope (AMEX 1000, Life Technologies, Carlsbad, CA, USA) at $\times 10$ magnification.

2.6. Statistical Analyses. Each experiment was repeated at least three times. Data are presented as means \pm standard error of the mean (SEM). Student's $t$-tests (unpaired, unequal variance) were used to compare two groups of independent samples for ROS expression. $P<0.05$ was considered to indicate statistical significance.

\section{Results}

\subsection{Changes in ROS Levels in the Absence of $\mathrm{H}_{2} \mathrm{O}_{2}$}

3.1.1. Changes in ROS Levels under Control Conditions. The absolute change in RFU values for the different treatment conditions was defined as the RFUs after treatment minus the RFUs before treatment. In the absence of $\mathrm{H}_{2} \mathrm{O}_{2}$ or any treatment, intracellular ROS levels began to increase slightly at 5 minutes and remained high at 60 minutes (for PC 3 cells, $29,893[ \pm 4087]$ at $5 \mathrm{~min}$ versus $47,169[ \pm 5451]$ at $60 \mathrm{~min}$; for Hs-680Tg cells, 15,817 [ \pm 945$]$ at 5 min versus 30,366 [ \pm 5002$]$ at $60 \mathrm{~min}$; and for HN5 cells, 22,501 [ \pm 2753$]$ at $5 \mathrm{~min}$ versus $46,577$ [ \pm 8787$]$ at $60 \mathrm{~min})$ and at a similar level at 90 minutes for all three cell lines (Figure 1).

3.1.2. Changes in ROS Levels after Treatment with $1 \%$ $\mathrm{CoCl}_{2} \cdot 6 \mathrm{H}_{2} \mathrm{O}$. Compared with the untreated control condition, intracellular ROS levels in cells treated with $1 \%$ $\mathrm{CoCl}_{2} \cdot 6 \mathrm{H}_{2} \mathrm{O}$ began to decrease as early as 5 minutes after treatment and remained at similar levels thereafter in all three cell lines (for PC3 cells, 11,329 [ \pm 930$]$ at 5 min versus $12,404[ \pm 935]$ at $90 \mathrm{~min}$; for Hs-680Tg cells, $5570[ \pm 494]$ at 5 min versus 8987 [ \pm 998 ] at $90 \mathrm{~min}$; and for HN5 cells, 9645 $[ \pm 1385]$ at $5 \mathrm{~min}$ versus $16,159[ \pm 1336]$ at $90 \mathrm{~min})(P<0.001$ versus control for all). At 5 minutes after treatment with $1 \%$ $\mathrm{CoCl}_{2} \cdot 6 \mathrm{H}_{2} \mathrm{O}$, the ROS levels were $37.9 \%$ of the control level in PC3 cells, $35.2 \%$ of the control level in the Hs- $680 \mathrm{Tg}$ cells, and $42.9 \%$ of the control level in the HN5 cells (Figure 1).

3.1.3. Changes in ROS Levels after Treatment with $2 \%$ NAC. Intracellular ROS levels in cells treated with $2 \%$ NAC were substantially lower than in the control condition $(P<0.001$ for all, in all three cell lines; for PC3 cells, 9046 [ \pm 927$]$ at $5 \mathrm{~min}$ versus $5571[ \pm 446]$ at $90 \mathrm{~min}$; for Hs-680Tg cells, $4396[ \pm 113]$ at $5 \mathrm{~min}$ versus 3388 [ \pm 458 ] at $90 \mathrm{~min}$; and for HN5 cells, 7238 $[ \pm 1147]$ at $5 \mathrm{~min}$ versus $5487[ \pm 604]$ at $90 \mathrm{~min})$. At 5 minutes after treatment with $2 \%$ NAC, ROS levels were $30.3 \%$ of the control level in the PC3 cells, $27.8 \%$ of the control level in the
Hs- $680 \mathrm{Tg}$ cells, and $32.2 \%$ of the control level in the HN5 cells (Figure 1).

3.1.4. Changes in ROS Levels after Treatment with Co:NAC $(1 \%: 2 \%)$. Treatment with Co:NAC $(1 \%: 2 \%)$ led to very small amounts of intracellular ROS at 5 minutes after treatment (PC3 cells, 1432 [ \pm 478$]$; Hs-680Tg cells, 277 [ \pm 90$]$; and HN5 cells, 1945 [ \pm 645$]$ ); by 60 and 90 minutes, intracellular ROS levels dropped to undetectable levels in all three cell lines. At 5 min after treatment with Co: NAC, ROS levels were $4.8 \%$ of the control level for PC 3 cells, $1.8 \%$ of the control level for Hs-680Tg cells, and $8.6 \%$ of the control level for HN5 cells $(P<0.001$ versus control for all) (Figure 1$)$.

\subsection{Changes in ROS Levels in the Presence of $\mathrm{H}_{2} \mathrm{O}_{2}$}

3.2.1. In the Presence of $\mathrm{H}_{2} \mathrm{O}_{2}(1000 \mu \mathrm{M})$. Untreated cells showed a slight increase in intracellular ROS levels relative to control cells (without $\mathrm{H}_{2} \mathrm{O}_{2}$ ) at 5 minutes. Notably, ROS levels greatly increased with time in all three cell lines thereafter (at 90 minutes: for PC3 cells, 123,613 [ $\pm 12,494], 255.9 \%$ of the control level; for Hs-680Tg cells, $172,750[ \pm 18,681], 543.2 \%$ of the control level; and for HN5 cells, 174,291 [ $\pm 14,274], 352.0 \%$ of the control level; $P<0.001$ for all) (Figure 1).

3.2.2. Changes in ROS Levels after Treatment with $1 \%$ $\mathrm{CoCl}_{2} \cdot 6 \mathrm{H}_{2} \mathrm{O}$. In the presence of $\mathrm{H}_{2} \mathrm{O}_{2}(1000 \mu \mathrm{M})$, treatment with $1 \% \mathrm{CoCl}_{2} \cdot 6 \mathrm{H}_{2} \mathrm{O}$ led to similar intracellular ROS levels in all three of cell lines at 5 minutes compared with the no treatment group. Beginning at 30 minutes and continuing to 90 minutes, intracellular ROS levels dropped significantly relative to the untreated condition (with $\mathrm{H}_{2} \mathrm{O}_{2}$ only) in all three cell lines (at 90 minutes: for PC3 cells, 63,547 [ \pm 6240$], 51.4 \%$ of untreated condition; for Hs-680Tg cells, $67,711$ [ \pm 4988$], 39.2 \%$ of untreated condition; and for HN5 cells, 79,249 [ \pm 6015$], 45.5 \%$ of untreated condition; $P<0.05$ for all). However, these values were significantly higher than those treated with $1 \% \mathrm{CoCl}_{2} \cdot 6 \mathrm{H}_{2} \mathrm{O}$ without $\mathrm{H}_{2} \mathrm{O}_{2}$ in all three cell lines at all 4 measurement points (for PC 3 cells, $306.3 \%$ at $5 \mathrm{~min}$ versus $512.3 \%$ at $90 \mathrm{~min}$; for $\mathrm{Hs}-680 \mathrm{Tg}$ cells, $574.6 \%$ at 5 min versus $753.4 \%$ at $90 \mathrm{~min}$; and for HN5 cells, $330.3 \%$ at $5 \mathrm{~min}$ versus $490.4 \%$ at $90 \mathrm{~min} ; P<0.001$ for all) (Figure 1).

3.2.3. Changes in ROS Levels after Treatment with $2 \%$ NAC. In the presence of $\mathrm{H}_{2} \mathrm{O}_{2}(1000 \mu \mathrm{M})$, treatment with $2 \%$ NAC led to ROS levels that were similar to those after $2 \%$ NAC without $\mathrm{H}_{2} \mathrm{O}_{2}$ and remained quite low over time in all three cell lines (at 90 minutes: for PC3 cells, 6774 [ \pm 617 ]; for Hs-680Tg cells, $4760[ \pm 231]$; and for HN5 cells, $6278[ \pm 727])$. These ROS levels were significantly lower than in the untreated condition (with $\mathrm{H}_{2} \mathrm{O}_{2}$ only) (for PC 3 cells, $23.4 \%$ of untreated condition at $5 \mathrm{~min}$ versus $5.5 \%$ of untreated condition at $90 \mathrm{~min}$; for Hs$680 \mathrm{Tg}$ cells, $18.5 \%$ of untreated condition at $5 \mathrm{~min}$ versus $2.8 \%$ of untreated condition at $90 \mathrm{~min}$; and for HN5 cells, $21.7 \%$ of untreated condition at $5 \mathrm{~min}$ versus $3.6 \%$ of untreated condition at $90 \mathrm{~min} ; P<0.001$ for all) (Figure 1).

3.2.4. Changes in ROS Levels after Treatment with Co:NAC $(1 \%: 2 \%)$. Treatment of cells with Co:NAC $(1 \%: 2 \%)$ in the 


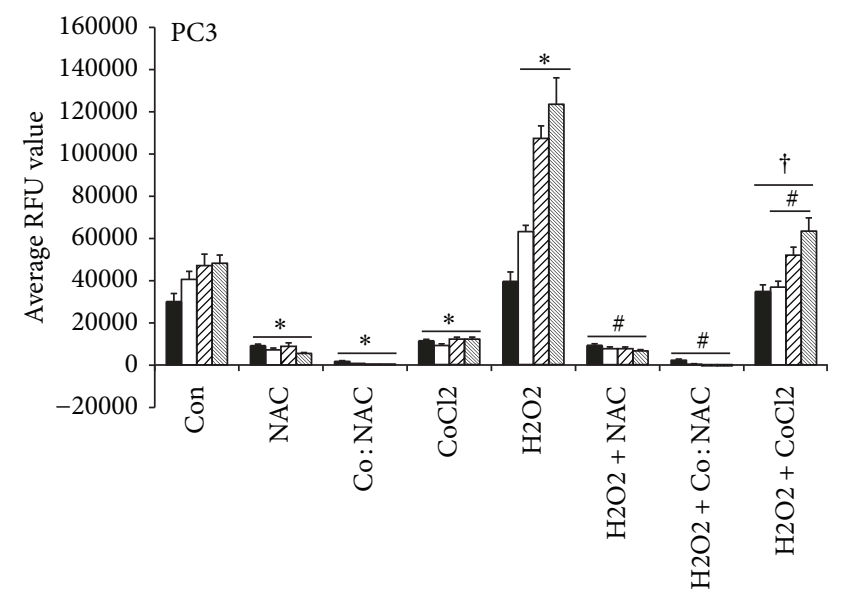

- $5 \mathrm{~min}$

․ $30 \mathrm{~min}$

๑ $60 \mathrm{~min}$

ه $90 \mathrm{~min}$
${ }^{*} P<0.001$ versus control

${ }^{\#} P<0.001$ versus $\mathrm{H}_{2} \mathrm{O}_{2}$

${ }^{\dagger} P<0.001$ versus $\mathrm{CoCl}_{2}$

(a)

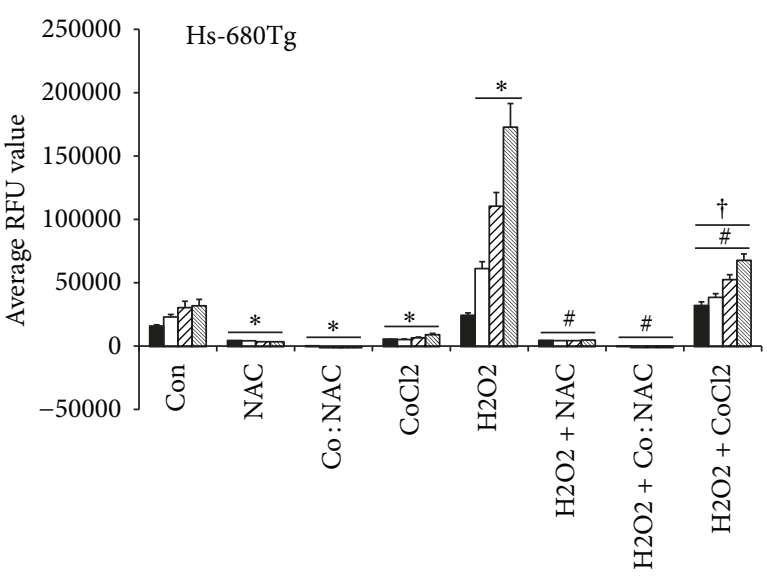

- $5 \mathrm{~min}$

$30 \mathrm{~min}$

๑ $60 \mathrm{~min}$

ه $90 \mathrm{~min}$

(b)

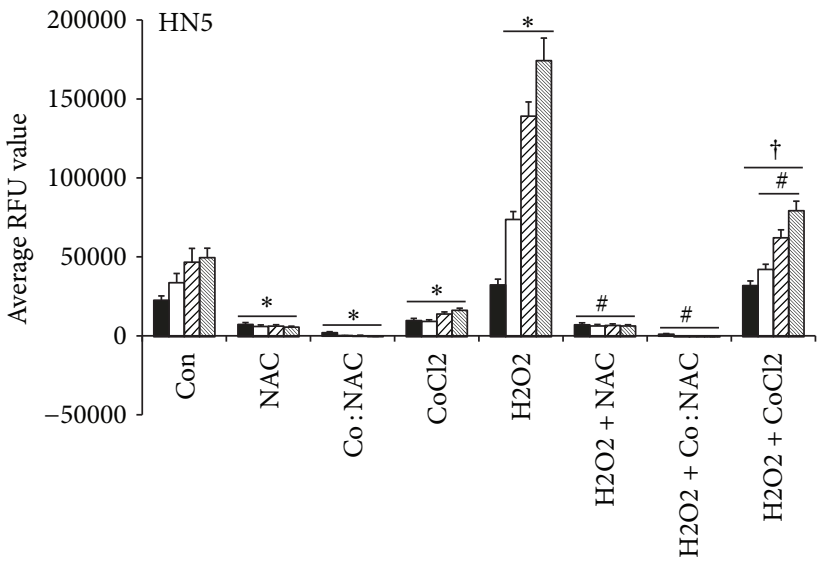

- $5 \mathrm{~min}$
$30 \mathrm{~min}$
घ $60 \mathrm{~min}$
$90 \mathrm{~min}$

${ }^{*} P<0.001$ versus control

${ }^{\#} \mathrm{P}<0.001$ versus $\mathrm{H}_{2} \mathrm{O}_{2}$

${ }^{\dagger} P<0.001$ versus $\mathrm{CoCl}_{2}$

(c)

FIGURE 1: Changes in intracellular reactive oxygen species (ROS) levels over time in response to various treatment conditions. Human prostate cancer cells (PC3, (a)), human normal tongue cells (Hs-680Tg, (b)), and human head and neck cancer cells (HN5, (c)) were treated with components of the novel MRI positive-contrast marker $\mathrm{C} 4$ as follows: $1 \%$ [w/v] $\mathrm{CoCl}_{2} \cdot 6 \mathrm{H} 2 \mathrm{O}, 2 \%$ [w/v] N-acetylcysteine (NAC), or the combined Co: NAC solutions ( $1 \%: 2 \%[\mathrm{w} / \mathrm{v}])$, in the presence or absence of $1000 \mu \mathrm{M} \mathrm{H}_{2} \mathrm{O}_{2}$. At 5, 30, 60, or 90 minutes after treatment, intracellular ROS levels were evaluated. Controls (Con) are cells not treated and not exposed to $\mathrm{H}_{2} \mathrm{O}_{2}$. The ROS levels were measured in terms of relative fluorescence units (RFUs) at excitation and emission wavelengths of $485 \mathrm{~nm}$ and $535 \mathrm{~nm}$. Values shown are means \pm SEM from at least 3 independent experiments. Student's $t$-tests (unpaired, unequal variance) were used for comparisons.

presence of $\mathrm{H}_{2} \mathrm{O}_{2}(1000 \mu \mathrm{M})$ led to very small amounts of intracellular ROS at $5 \mathrm{~min}$ (similar to levels in the Co: NAC without $\mathrm{H}_{2} \mathrm{O}_{2}$ condition) in all three cell lines (for PC3 cells, 2100 [ \pm 573 ]; for Hs-680Tg cells, 175 [ \pm 119$]$; and for HN5 cells, $1009[ \pm 404])$. These levels were considerably lower than the untreated condition (with $\mathrm{H}_{2} \mathrm{O}_{2}$ only) at $5 \mathrm{~min}$ (for PC3 cells, $5.3 \%$ of the untreated condition; for Hs-680Tg cells, $0.7 \%$ of the untreated condition; and for HN5 cells, $3.1 \%$ of the untreated condition; $P<0.001$ for all) and further decreased over time to reach undetectable levels at 60 and 90 minutes in all three cell lines studied (Figure 1).

3.3. Cell Morphology under Treatment. Compared with untreated cells, there was no histopathologic evidence of changes in cell morphology at 90 minutes after treatment with the greatest clinical exposure concentration of $\mathrm{C} 4$ or its components $\left(1 \% \mathrm{CoCl}_{2} \cdot 6 \mathrm{H}_{2} \mathrm{O}\right.$, or the $2 \% \mathrm{NAC}$, or the Co : NAC $[1 \%: 2 \%]$ ) (Figure 2 ). 


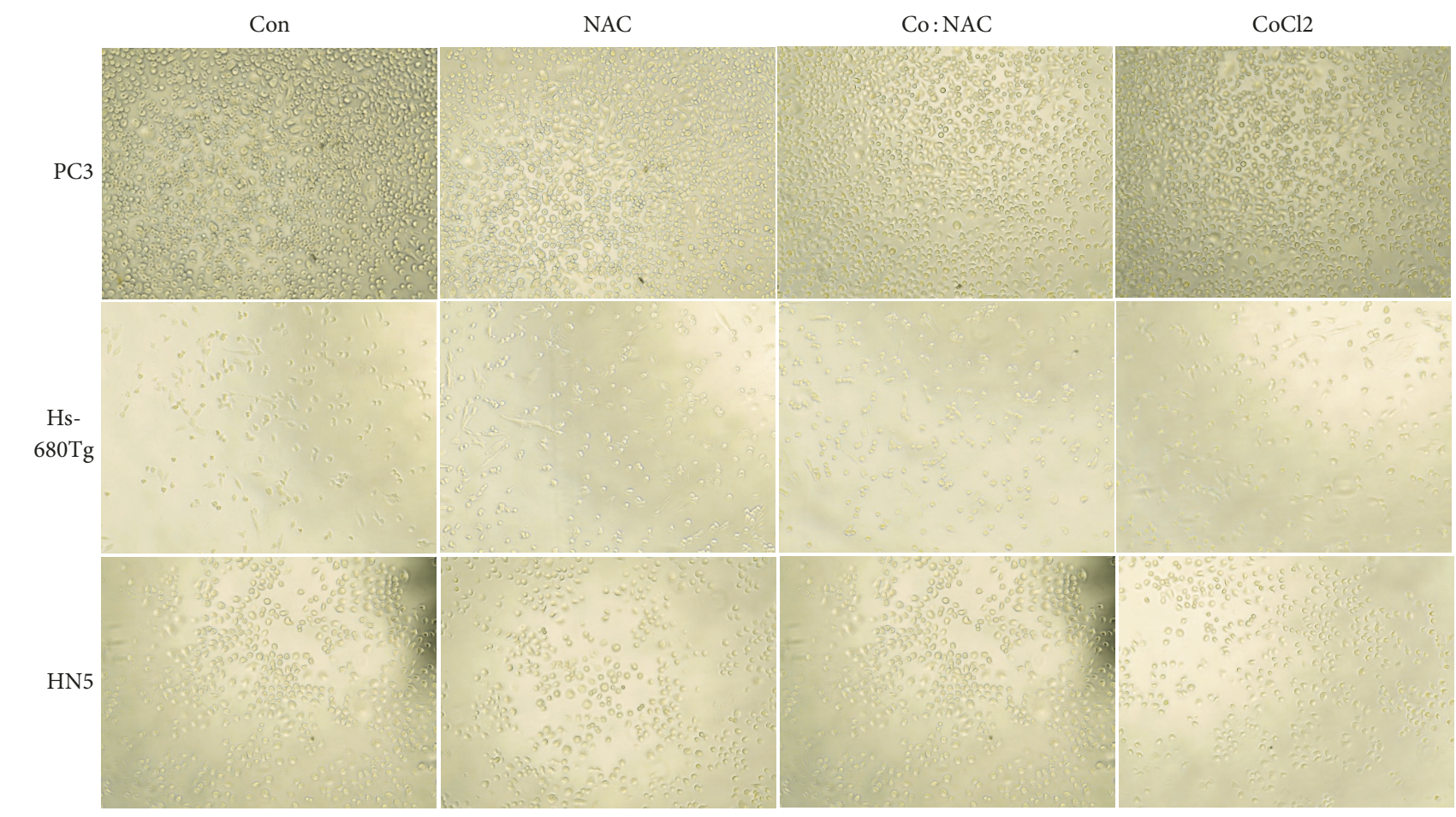

FIGURE 2: Cell morphology after various treatment conditions. Human prostate cancer cells (PC3), human normal tongue cells (Hs-680Tg), and human head and neck cancer cells (HN5) were treated with the greatest clinical exposure concentration of the novel MRI Co: NAC positive-contrast agent for $\mathrm{C} 4$ marker or its components $\left(1 \%[\mathrm{w} / \mathrm{v}] \mathrm{CoCl}_{2} \cdot 6 \mathrm{H} 2 \mathrm{O}, 2 \%[\mathrm{w} / \mathrm{v}] \mathrm{N}\right.$-acetylcysteine (NAC), or the combined Co : NAC solutions $(1 \%: 2 \%[\mathrm{w} / \mathrm{v}]))$. At 90 minutes after treatment, cell morphology pictures were taken with a bright field Evos XL core microscope (AMEX 1000, Life Technologies, Carlsbad, CA, USA) at ×10 magnification. Controls (Con) were untreated cells.

\section{Discussion}

In this study, we used a well-established ROS assay, which can be used to measure ROS (hydroxyl, peroxyl, and other reactive oxygen species) activity within a cell, to evaluate the influence of $\mathrm{C} 4$ and its components on the intracellular levels of ROS. The maximum tolerance concentration $(1000 \mu \mathrm{M})$ for $\mathrm{H}_{2} \mathrm{O}_{2}$ (i.e., that which does not lead to cell death within 24 hours) that could induce the highest levels of ROS in cells was used. We measured ROS levels over time (at 5, 30, 60 , and 90 minutes after treatment) within human prostate cancer PC3 cells, human normal tongue Hs-680Tg cells, and human head and neck cancer HN5 cells after treatment with $1 \% \mathrm{CoCl}_{2} \cdot 6 \mathrm{H}_{2} \mathrm{O}$, or $2 \% \mathrm{NAC}$, or the combined form $\mathrm{Co}: \mathrm{NAC}$ $(1 \%: 2 \%)$, in the presence or absence of $\mathrm{H}_{2} \mathrm{O}_{2}$. Standard curves were used as a quality control in these experiments. We found that one of the components of the MRI positivecontrast marker C4 (2\% NAC) drastically suppressed both background ROS and the ROS in the presence of $\mathrm{H}_{2} \mathrm{O}_{2}$ in all three cell lines at all of the tested times $(P<0.001$ for all). The other component of $\mathrm{C} 4\left(1 \% \mathrm{CoCl}_{2}\right)$ also significantly suppressed both background ROS levels $(P<0.001$ for all) and the ROS in the presence of $\mathrm{H}_{2} \mathrm{O}_{2}$ at 30,60, and 90 minutes after treatment in all three cell lines $(P<0.05$ for all). Notably, the C4 marker itself (Co:NAC [1\%:2\%]) drastically suppressed both basal and $\mathrm{H}_{2} \mathrm{O}_{2}$-related ROS levels as early as 5 minutes after treatment $(P<0.001$ for all $)$ and reduced ROS levels to undetectable levels at 60 and 90 minutes in all three cell lines. Moreover, no cell morphology change was observed at 90 minutes after cells were exposed to the greatest clinical exposure concentration of $\mathrm{C} 4$ or its components. These findings suggest that patients given $\mathrm{C} 4$ for seed localization during MRI-guided brachytherapy are not at risk of enhanced ROS generation from the presence of $\mathrm{Co}(\mathrm{II})$ in the $\mathrm{C} 4$ complex.

Ionized cobalt $\left[\mathrm{Co}^{2+}\right.$, or $\left.\mathrm{Co}(\mathrm{II})\right]$ can generate ROS $[10-$ 12] in cultured cells. ROS can induce direct cellular injury, which triggers a cascade of radical reactions enhancing secondary ROS generation. Excessive generation of ROS may further stimulate inflammatory processes involving secretion of chemotactic factors, growth factors, proteolytic enzymes, lipoxygenases, and cyclooxygenase, leading to the inactivation of antiproteolytic enzymes and the release of signaling proteins [12]. ROS is also generated by the formation of coordination complexes with metals and some chelating agents [16]. Previous reports have demonstrated that chelation of $\mathrm{Co}$ (II) can change its oxidation potential [17-19]. Mello-Filho and Meneghini and Sugiyama et al. investigated ${ }^{\circ} \mathrm{OH}$ radical generation by $\mathrm{Co}(\mathrm{II})$ in the presence of chelators such as B-alanyl-3-methyl-L-histidine (anserine) and 1,10-phenanthroline and deferoxamine [20, 21]. Mao et al. reported that the extent of $\mathrm{Co}(\mathrm{II})$-mediated generation of ROS from $\mathrm{H}_{2} \mathrm{O}_{2}$ depended on the properties of chelators [19], but they did not evaluate NAC. In the creation of C4, 
we chose NAC as the agent to block ROS from $\mathrm{Co}(\mathrm{II})$, because NAC has anti-ROS activity and can also function as an ROS inhibitor $[22,23]$. In the current study, the presence of $2 \%$ NAC drastically suppressed $\mathrm{H}_{2} \mathrm{O}_{2}$-related ROS in HN5 cells (by up to $96.4 \%$ ), Hs-680Tg cells (by up to $97.2 \%$ ), and PC3 cells (by up to $94.5 \%$ ) at 5-90 minutes after treatment. These findings are consistent with another report from Zou and colleagues [24]. The greater relevance to our study was their finding that treatment with NAC significantly inhibited $\mathrm{CoCl}_{2}$-induced apoptosis via blocking ROS production. Similarly, Jung and Kim [25] also found that NAC attenuated ROS levels induced by $\mathrm{CoCl}_{2}$ in the PC12 cells. Notably, when the MRI-compatible marker C4 itself (Co:NAC $[1 \%: 2 \%]$ ) was administrated, the ROS at the presence of $\mathrm{H}_{2} \mathrm{O}_{2}$ in $\mathrm{HN} 5$, Hs-680Tg, and PC3 cells was suppressed to undetectable levels starting at 30 minutes (for HN5 and Hs-680Tg cells) or at 60 minutes (PC3) after treatment. Collectively, this evidence supports the safety of the MRI marker $\mathrm{C} 4$ for clinical use in terms of the risk of generating ROS from interactions of Co(II) with $\mathrm{H}_{2} \mathrm{O}_{2}$.

In the current study, we observed to our surprise that $1 \%$ $\mathrm{CoCl}_{2} \cdot 6 \mathrm{H} 2 \mathrm{O}$, one of the components of the MRI-compatible marker $\mathrm{C} 4$, could also reduce background ROS levels in all three cell lines. Even though there was $\mathrm{H}_{2} \mathrm{O}_{2}$-related ROS generation in the presence of $1 \% \mathrm{CoCl}_{2} \cdot 6 \mathrm{H} 2 \mathrm{O}$, those ROS levels were significantly decreased in HN5 cells (by up to $55.4 \%$ ), Hs-680Tg cells (by up to 60.8\%), and PC3 cells (by up to $51.5 \%$ ) over time (30-90 minutes after treatment).

Our study did have limitations, since the conclusions were based on the investigation of one human prostate cancer, one human normal tongue, and one human head and neck cancer cell line under different treatment conditions. Further studies with more cell lines and in vivo models are warranted.

\section{Conclusions}

We conclude that, in human prostate cancer PC3 cells, human normal tongue Hs-680Tg cells, and human head and neck cancer HN5 cells, significant DCFH oxidation does not occur in the presence of $\mathrm{CoCl}_{2}$ or NAC alone or in combination; and induced (by the presence of $\mathrm{H}_{2} \mathrm{O}_{2}$ ) DCFH oxidation is blocked by $\mathrm{CoCl}_{2}$ and NAC and by Co: NAC. These findings provide support for the safe use of $\mathrm{C} 4$, in which $1 \%$ of the component $\mathrm{CoCl}_{2} \cdot 6 \mathrm{H}_{2} \mathrm{O}$ is complexed with $2 \%$ of the chelating antioxidant NAC as a positive-contrast MRI marker for men with prostate cancer undergoing brachytherapy.

\section{Conflicts of Interest}

S. J. Frank and K. S. Martirosyan are cofounders of C4 Imaging, LLC. S. J. Frank is an advisory board member and consultant for Varian Medical Systems, Inc. All other authors declare no conflicts of interest.

\section{Acknowledgments}

This work was supported in part by Cancer Center Support (Core) Grant CA016672 from the National Cancer Institute to MD Anderson Cancer Center, the Prostate Cancer
Foundation, the University Cancer Foundation via the Sister Institution Network Fund, the Institutional Research Grant program, and startup funds to Steven J. Frank from the University of Texas MD Anderson Cancer Center. The authors would like to thank Jibin Ding from the Department of Integrative Medicine and Lisa Norberg from the Department of Cancer Biology at MD Anderson for technical assistance. They also thank Christine F. Wogan from MD Anderson's Division of Radiation Oncology for editorial assistance.

\section{References}

[1] R. L. Siegel, K. D. Miller, and A. Jemal, "Cancer statistics, 2015," CA: A Cancer Journal for Clinicians, vol. 65, no. 1, pp. 5-29, 2015.

[2] A. V. Taira, G. S. Merrick, W. M. Butler et al., "Long-term outcome for clinically localized prostate cancer treated with permanent interstitial brachytherapy," International Journal of Radiation Oncology, Biology, Physics, vol. 79, no. 5, pp. 13361342, 2011.

[3] M. J. Zelefsky, X. Pei, J. F. Chou et al., "Dose escalation for prostate cancer radiotherapy: predictors of long-term biochemical tumor control and distant metastases-free survival outcomes," European Urology, vol. 60, no. 6, pp. 1133-1139, 2011.

[4] T. J. Strom, A. A. Cruz, N. B. Figura et al., "Health-related quality-of-life changes due to high-dose-rate brachytherapy, low-dose-rate brachytherapy, or intensity-modulated radiation therapy for prostate cancer," Brachytherapy, vol. 14, no. 6, pp. 818-825, 2015.

[5] P. W. McLaughlin, S. Troyer, S. Berri et al., "Functional anatomy of the prostate: Implications for treatment planning," International Journal of Radiation Oncology, Biology, Physics, vol. 63, no. 2, pp. 479-491, 2005.

[6] D. F. Dubois, B. R. Prestidge, L. A. Hotchkiss, W. S. Bice Jr., and J. J. Prete, "Source localization following permanent transperineal prostate interstitial brachytherapy using magnetic resonance imaging," International Journal of Radiation Oncology, Biology, and Physics, vol. 39, no. 5, pp. 1037-1041, 1997.

[7] S. J. Frank, R. J. Stafford, J. A. Bankson et al., "A novel MRI marker for prostate brachytherapy," International Journal of Radiation Oncology, Biology, Physics, vol. 71, no. 1, pp. 5-8, 2008.

[8] S. J. Frank, R. C. Tailor, R. J. Kudchadker et al., "Anisotropy characterization of I-125 seed with attached encapsulated cobalt chloride complex contrast agent markers for MRI-based prostate brachytherapy," Medical Dosimetry, vol. 36, no. 2, pp. 200-205, 2011.

[9] ATSDR - Toxicological Profile for Cobalt [homepage on internet] 2004. https://www.atsdr.cdc.gov/ToxProfiles/tp.asp?id= 373\&amp;tid=64, and https://www.atsdr.cdc.gov/ToxProfiles/ tp33.pdf.

[10] V. T. Ho and H. F. Bunn, "Effects of transition metals on the expression of the erythropoietin gene: Further evidence that the oxygen sensor is a heme protein," Biochemical and Biophysical Research Communications, vol. 223, no. 1, pp. 175-180, 1996.

[11] V. Battaglia, A. Compagnone, A. Bandino et al., "Cobalt induces oxidative stress in isolated liver mitochondria responsible for permeability transition and intrinsic apoptosis in hepatocyte primary cultures," The International Journal of Biochemistry \& Cell Biology, vol. 41, no. 3, pp. 586-594, 2009.

[12] S. S. Leonard, G. K. Harris, and X. Shi, "Metal-induced oxidative stress and signal transduction," Free Radical Biology \& Medicine, vol. 37, no. 12, pp. 1921-1942, 2004. 
[13] D. Beyersmann and A. Hartwig, "Carcinogenic metal compounds: recent insight into molecular and cellular mechanisms," Archives of Toxicology, vol. 82, no. 8, pp. 493-512, 2008.

[14] S. J. Frank, M. J. Johansen, K. S. Martirosyan et al., "A biodistribution and toxicity study of cobalt dichloride- $\mathrm{N}$-acetyl cysteine in an implantable MRI marker for prostate cancer treatment," International Journal of Radiation Oncology, Biology, Physics, vol. 85, no. 4, pp. 1024-1030, 2013.

[15] D. A. Bass, J. W. Parce, L. R. Dechatelet et al., "Flow cytometric studies of oxidative product formation by neutrophils: A graded response to membrane stimulation," Journal of Immunology, vol. 130, no. 4, pp. 1910-1917, 1983.

[16] X. Shi, N. S. Dalal, and K. S. Kasprzak, "Generation of free radicals from model lipid hydroperoxides and $\mathrm{H} 2 \mathrm{O} 2$ by $\mathrm{Co}(\mathrm{II})$ in the presence of cysteinyl and histidyl chelators," Chemical Research in Toxicology, vol. 6, no. 3, pp. 277-283, 1993.

[17] M. K. Eberhardt, C. Santos, and M. Ann Soto, "Formation of hydroxyl radicals and $\mathrm{Co} 3+$ in the reaction of Co2+-EDTA with hydrogen peroxide. catalytic effect of Fe3+," BBA - General Subjects, vol. 1157, no. 1, pp. 102-106, 1993.

[18] P. M. Hanna, M. B. Kadiiska, and R. P. Mason, "Oxygen-derived free radical and active oxygen complex formation from cobalt(II) chelates in vitro," Chemical Research in Toxicology, vol. 5, no. 1, pp. 109-115, 1992.

[19] Y. Mao, K. J. Liu, J. J. Jiang, and X. Shi, “Generation of reactive oxygen species by $\mathrm{Co}$ (II) from $\mathrm{H}_{2} \mathrm{O}_{2}$ in the presence of chelators in relation to DNA damage and 2'-deoxyguanosine hydroxylation," Journal of Toxicology and Environmental Health, vol. 47, no. 1, pp. 61-75, 1996.

[20] A. C. Mello-Filho and R. Meneghini, "Iron is the intracellular metal involved in the production of DNA damage by oxygen radicals," Mutation Research, vol. 251, no. 1, pp. 109-113, 1991.

[21] M. Sugiyama, K. Tsuzuki, and N. Haramaki, "Influence of o-phenanthroline on DNA single-strand breaks, alkali-labile sites, glutathione reductase, and formation of chromium(V) in Chinese hamster V-79 cells treated with sodium chromate(VI)," Archives of Biochemistry and Biophysics, vol. 305, no. 2, pp. 261266, 1993.

[22] S.-Y. Sun, "N-acetylcysteine, reactive oxygen species and beyond," Cancer Biology \& Therapy, vol. 9, no. 2, pp. 109-110, 2010.

[23] L. Raj, T. Ide, A. U. Gurkar et al., "Selective killing of cancer cells by a small molecule targeting the stress response to ROS," Nature, vol. 475, no. 7355, pp. 231-234, 2011.

[24] W. Zou, M. Yan, and W. Xu, "Cobalt chloride induces PC12 cells apoptosis through reactive oxygen species and accompanied by AP-1 activation," Journal of Neuroscience Research, vol. 64, no. 6, pp. 646-653, 2001.

[25] J. Y. Jung and W. J. Kim, "Involvement of mitochondrial- and Fas-mediated dual mechanism in $\mathrm{CoCl}_{2}$-induced apoptosis of rat PC12 cells," Neuroscience Letters, vol. 371, no. 2-3, pp. 85-90, 2004. 

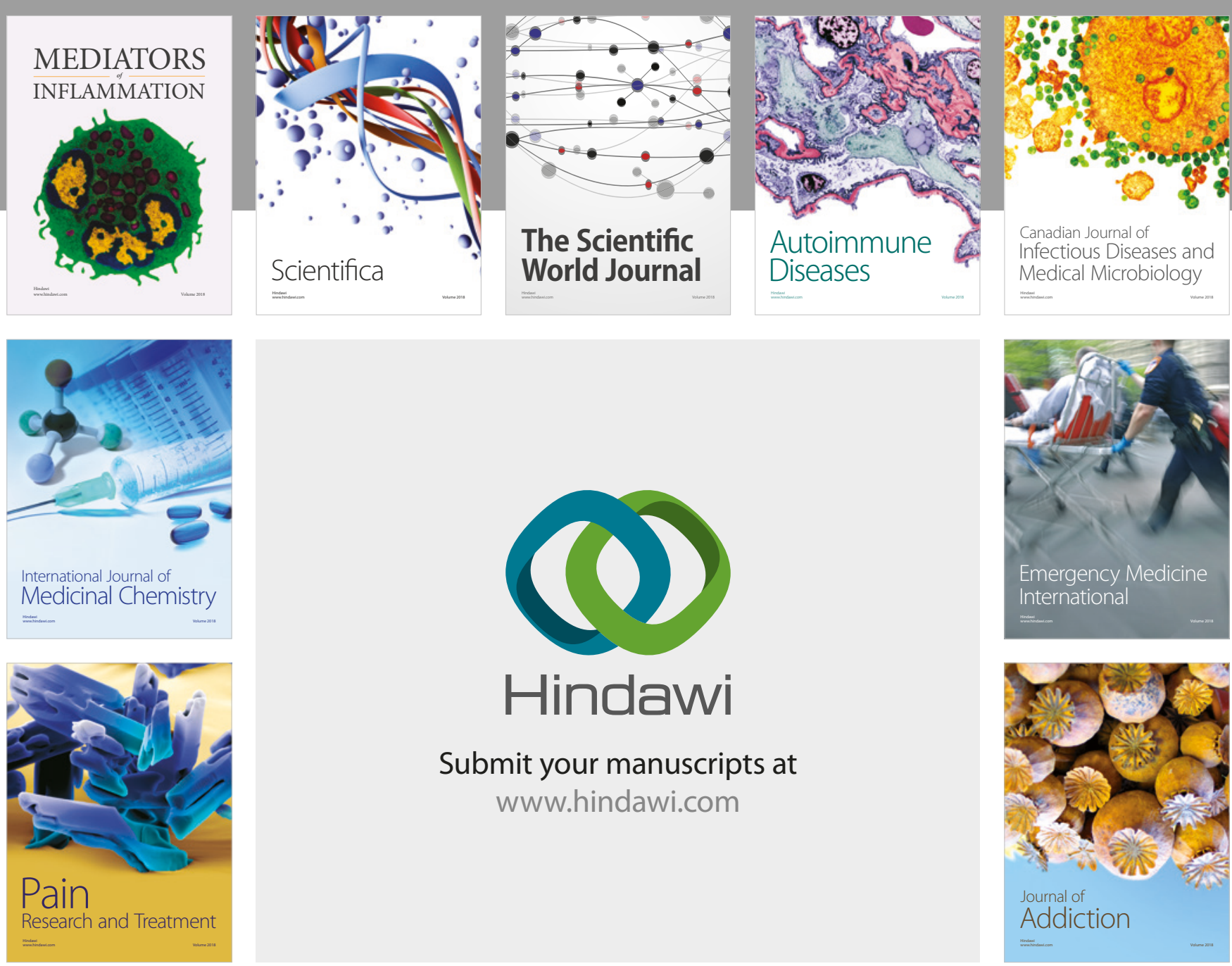

Canadian Journal of
Infectious Diseases and Medical Microbiology

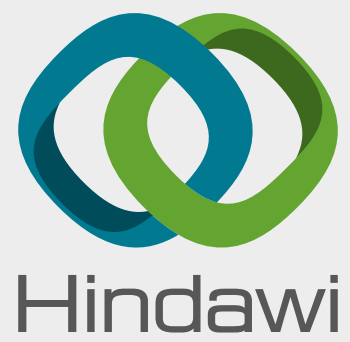

Submit your manuscripts at

www.hindawi.com
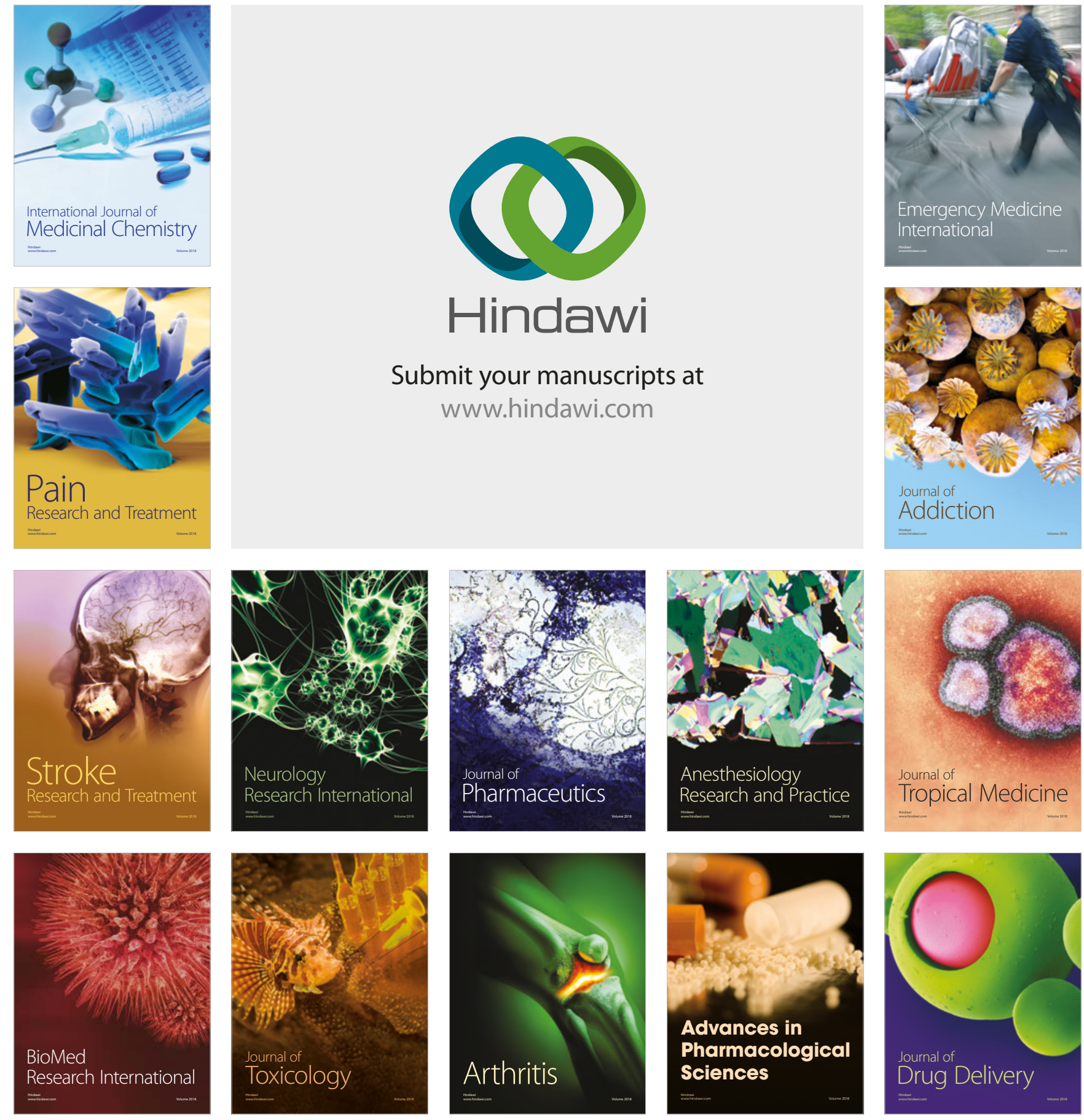